\title{
ARTICLE 27 OF COMPETITION LAW AND WHAT LIES BENEATH
}

\author{
Perdana A. Saputro ${ }^{1}$
}

\begin{abstract}
This article discuss about Article 27 of Law No. 5 Year 1999 on the Restriction of Monopoly Practices and Unfair Business Practices ("Competition Law"). One may wonder the rigorousness to the application of Article 27 which arguably could ban any merger which meets market test without conducting any competitive assessment. For this, the law has been presumed that the acquisition or controlling of large market share from merger is per se illegality.

Further, the effects of Article 27 would be discussed in this paper. A merger review itself is not an easy task and tends to bring complex issues that one needs to be dealt with. Things get more complicated when one deals with the merger application in developing countries since there are various aspects that need to be taken account by the respective antitrust authority (including Indonesia) Obviously, every country needs to set up its competition law in accordance with its own economic characteristics and conditions.

Many have argued as to point out the severe condition in market as a result of high concentration of competition. But more of them argued otherwise, as it could positively pushed on the market. This article would also include best practices from US and EU competition law practices regarding the issue at hand, as well as the relationship of merger control and practices in developing countries. The article offers suggestion with regard to the current approach to Article 27 of the Competition Law and from EU and US best practice which could be used for the benefit of Indonesia's competition law especially to the application of Article 27.
\end{abstract}

Keywords: competition, market, merger

\section{Introduction}

27 is a cursed number for those famous musicians who all died tragically at the age of $27^{2}$. Whether (Article) 27 would also become a draconian number for business communities, it is a fair question that one could ask for. The Article 27 that becomes the subject of this writing is Article 27 of Law No. 5 Year 1999 on the Restriction of Monopoly Practices and Unfair Business Practices ("Competition Law") 3 . Under this law, Article 27 restricts any merger which basically controls (i) more than $50 \%$ for one undertaking or (ii) more than $75 \%$ along with two or three undertakings. This provision, however, does not contain

\footnotetext{
${ }^{1}$ Attorney at Melli Darsa \&Co.

${ }^{2}$ Brian Jones, Jimi Hendrix, Janis Joplin, Jim Morrison, Kurt Cobain, and Amy Winehouse.

${ }^{3}$ Law No. 5 Year 1999 on the Restriction of Monopoly Practices and Unfair Business Practices SG $1999-103$.
} 
the element of 'that could result in the occurrence of monopolistic practice and/ or unfair business competition' which demands a further analysis on the market effect. Clearly, from the way it is structured, Article 27 focuses on market concentration rather than the market effects. One may wonder the rigorousness to the application of Article 27 which arguably could ban any merger which meets the said market test without conducting any competitive assessment. For this, the law has been presumed that the acquisition or controlling of large market share from merger is per se illegality. Whether it is the correct approach for Indonesia market (which is, perhaps, driven more by historical accident) or it should actually demand a new approach, it is something that is worth to be analyzed further.

This paper will critically analyze the current approach of Article 27 and demonstrate certain shortcomings from the structure of Article 27. Further, the effects of Article 27 would also be discussed in this paper - if one would maintain the current structure. A merger review itself is not an easy task and tends to bring complex issues that one needs to be dealt with. The process of 'mergers have always been sort of an enigma in the theory of the firm'4. In dealing with a merger control, Posner also added 'there will of course be great difficulty in deciding what that threshold is, just as it is difficult, in fact impossible, to determine when day ends and night begins ${ }^{5}$. Things get more complicated when one deals with the merger application in developing countries since there are various aspects that need to be taken account by the respective antitrust authority (including the Indonesian Competition Commission (Komisi Pengawasan Persaingan Usaha - "KPPU")). It has been held that every country needs to set up its competition law in accordance with its own economic characteristics and conditions, primarily the application of it in the developing countries ${ }^{6}$. These needs and conditions include: (i) the economics characteristic of the respective developing countries, (ii) relatively concentrated nature of most product markets, (iii) the high concentration of ownership, and (iv) shortage of finance ${ }^{7}$. Inevitably, the above notions would also be applied to our very beloved country, Indonesia.

In discussing the main topic of this article, this paper will be divided into the following sections: (i) the first section will discuss the current structure of Article 27 and the approach that has been taken by the KPPU in applying this article. Under the current structure, Article 27 rests under two main assumptions which are (a) acquiring a large market shares or creating an oligopolistic market would bring no benefit to the market or society. In a simple word, being big is bad and (b) controlling a large market share equals to possessing a market power. These notions were supported with two cases which involved Article 27

${ }^{4}$ DC Mueller, A theory of conglomerate mergers, (1982) 82 Quarterly Journal of Economics 643, 643.

${ }^{5}$ Richard Posner, Antitrust Law 2nd ed., (Chicago Press, 2001), 123.

${ }^{6}$ Pradeep S. Mehta, Competition policy in developing countries: an asia pacific perspective (Bulletin on Asia-Pasific Perspective 2002/03), 81, accessed via http://www.unescap.org/drpad/publication/ bulletin\%202002/ch2.pdf

${ }^{7}$ Rajan Dhanjee, Mergers and developing countries - trends, effects and policies (1993) World Competition 5, 6 
as its main contention i.e. Cineplex 21 case $^{8}$ and Temasek case ${ }^{9}$. Interestingly, KPPU has taken different approaches to these cases. This section would also critically assess the approach of the KPPU Regulation No. 7 Year 2011 regarding the Guideline on the application of Article 27 ("KPPU Guidance Art. 27"); (ii) the second section will further analyse whether the notion of 'big is bad' is a proper approach. Is it really bad after all? One has argued the high concentration tends to result in a severe condition to the respective market. However, many have argued a dominant company could also contribute positive impacts as it can accelerate innovation or create economics of scale and scope. These big companies need to outperform their competitors with new and innovative products. Certain prominent scholars' views will also be added in this paper to give more colour to the concerned discussion. This section would also include best practices from US and EU competition law practices regarding the issue at hand; (iii) the third section would discuss the relationship of merger control and the developing countries which is somewhat problematic. Whether actually a merger control is ever required for the developing countries is an open issue. A discussion on the key requirements for the respective antitrust authority will also be discussed herein; and (iv) the final section will offer suggestion with regard to the current approach to Article 27 of the Competition Law and what lessons that can be drawn from EU and US best practice which could be used for the benefit of Indonesia's competition law especially to the application of Article 27. It is hoped that this article will provide, however modest, a valuable contribution for the development of Article 27 going forward and the improvement of the Competition Law in Indonesia, in general.

\section{The current structure of Article 27}

Article 27 restricts an undertaking from owning a majority of shares in several companies conducting the same business activities in the same relevant market if such ownership results in (i) one undertaking or a group of undertakings controlling more than $50 \%$ of the relevant market or (ii) two or three undertakings or groups of undertakings controlling more than $75 \%$ of the relevant market. ${ }^{10}$ It is a stand alone provision and focuses more on the creation of concentration by one or more undertakings or group of undertakings. What is more important is that it has no element of "could result in the occurrence of monopolistic practices and/or unfair business competition". The violator will be deemed to breach Article 27 if it merely meets all elements of Articles 27 without the need to establish whether such conduct could result in the occurrence of monopolistic practices and/or unfair business competition. For blocking the merger, one may only put forward a suitable market definition to meet the Article 27 test. ${ }^{11}$ Putting in a simple word, it has the structure of a per se illegality provision. It could also arguably restrict any merger fall below the thresholds as set forth under Government Regulation No. 57 of 2010 on the

\footnotetext{
${ }^{8}$ KPPU Case No. 05/KPPU-L/2002 on Cineplex 21.

${ }^{9}$ KPPU Case No.07/KPPU-L/2007 on Temasek (divestment of Indosat).

${ }^{10}$ In practice, the KPPU will take into account the top 3 largest companies.

${ }^{11}$ This is arguably one of the main drawbacks of Article 27.
} 
Merger or Amalgamation and Shares Acquisition of the Company which Could Cause the Monopolistic Practices and Unfair Business Practices ("GR No. 57") which presumably has less significant effect to the market ${ }^{12}$. These obviously have a broad repercussion. Turner warns that a broad restriction of mergers may impose serious burdens upon the undertakings who wish to conduct merger transactions for valid business reasons ${ }^{13}$. Sometimes, a merger will often enhance economic conditions of the merged firms by creating substantial economies of scale and minimizing business risk, e.g. bankruptcy. ${ }^{14}$ For this reason, these assumptions may need to be tested further, especially from the economic analysis perspectives.

One may note that this provision may be influenced by the financial crisis which took place in 1997 which was caused, inter alia, by conglomerates failures and more conspicuously the conglomerates were mostly formed and dominated by a certain number of political power-connected families' circles ${ }^{15}$. At that time, the concentrations were not created through effective competition instead were created among themselves illicitly. ${ }^{16}$ These concentrations were created and maintained by the closed ties between certain business undertakings and the political elite which had caused severe market distortions in Indonesia ${ }^{17}$. This condition has led the public's perception with a lasting repugnance to big business by associating all conglomerate behavior with anticompetitive conduct $^{18}$. One could say that the adoption of Article 27 was to prevent such severe market distortions to be taken place again in the future. Enough is enough, probably is what the drafters had in mind, at that time. In light of this, one may conclude that the drafters stand on two fundamental assumptions in connection with Article 27 which are: firstly, acquiring a large market shares or creating an oligopolistic market would only bring losses to the wider society. In other words, being big is absolutely bad. Secondly, controlling a large market share equals to possessing a market power.

\section{A. Article 27 in action}

There are only two cases which use Article 27 so far, namely Cineplex 21 (2002) and Temasek (2007) but KPPU has applied different approach in these cases.

${ }^{12}$ Government Regulation No. 57 of 2010 on the Merger or Amalgamation and Shares Acquisition of the Company which Could Cause the Monopolistic Practices and Unfair Business Practices, SG 2010 89. One may argue that most of all mergers which meet the Article 27 test would also likely to meet the threshold as meant in GR No. 57. $1313,1317$.

${ }^{13}$ Donald F. Turner, Conglomerate mergers and section 7 of the Clayton Act (1965) 78 Harv.L.R

${ }^{14}$ Ibid.

15 United Nations Committee on Trade and Development (UNCTAD), Voluntary peer review on competition law: Indonesia (UNCTAD, 2009), 22, accessed via: http://www.unctad.org/en/docs/ ditcclp20091_en.pdf

${ }^{16}$ Ibid.

${ }^{17}$ Pande Radja Silalahi, Urgency of competition law (undated), 10, accessed via http://www.jftc. go.jp/eacpf/01/pprs.pdf.

${ }^{18}$ UNCTAD, Voluntary peer review on competition law: Indonesia (UNCTAD, 2009), 22, accessed via http://www.unctad.org/en/docs/ditcclp20091_en.pdf. 
In Cineplex 21 case, KPPU has taken a per se approach by finding PT Nusantara Sejahtera Raya guilty for controlling majority shares in two companies which control more than $50 \%$ market shares of movie theatre in Surabaya without making any assessment to reveal whether such merger could result in the occurrence of monopolistic practices and/or unfair business competition in the respective markets ${ }^{19}$. In contrast, in proving the illegality conduct of Temasek group, KPPU has taken a broader approach ${ }^{20}$ (if not a rule of reason approach) that not only must KPPU prove the Article 27 test but KPPU must also make an assessment of whether there are (i) an abuse of dominance position and (ii) a negative effect to the competition level resulting from that acquisition ${ }^{21}$. In Temasek case, one could interpret that KPPU actually acknowledges that there is more than just a market concentration in assessing the merger. Effectively, this double standard may create confusion to the business communities on how to understand the applicability of Article 27.

However, KPPU Guidance 27 confirms that Article 27 is a per se provision ${ }^{22}$. This guideline effectively empowers the KPPU to scrutinize and block any merger even to the merger where it does not raise any significant distortion to the competition to the extent such mergers meet the Article 27 test $^{23}$. It definitely raises a concern that the Competition Law may have lost its essence since the law were supposedly created to manifest and/or enhance consumer welfare and not the other way around. This may be in line with Bork's doubt with regard to the application of the competition law as there were many public monopolization cases have actually restricted competition in which they were supposed to protect and foster the competition. ${ }^{24}$

\section{Big is bad?}

The notion of big is bad may have valid ground primarily if one may take a look at the early days of US and EU competition law. It is well established that a dominant company (controlling large market shares) tends to create adverse impacts to the market ${ }^{25}$. This standpoint is well supported by Harvard School where S-C-P paradigm was introduced. Under this paradigm, 'certain industry structures, particularly high concentration accompanied by high entry barriers, dictate that the firms in that industry will engage in certain kinds of conduct, such as oligopoly behavior. This behavior would then lead to poor economic performance, namely, reduced output and monopoly prices ${ }^{26}$. One way to deal

${ }^{19}$ KPPU Case No. 05/KPPU-L/2002 on Cineplex 21.

${ }^{20} \mathrm{KPPU}$ had intentionally not use the term of rule of reason.

${ }^{21}$ KPPU Case No.07/KPPU-L/2007 on Temasek (divestment of Indosat).

${ }^{22}$ KPPU Guidance Art. 27, 22.

${ }^{23}$ Ibid.

${ }^{24}$ William H. Page and John E.Lopatka, The Microsoft Case, Antitrust, High Technology and Consumer Welfare $1^{\text {st }}$ ed (The University of Chicago Press, 2007), 3. Robert Bork, The Antitrust Paradox (1978).

${ }^{25}$ Herbert Hovenkamp, Federal Antitrust Policy the Law of Competition and its Practices 3rd ed. (Thomson West, 2005), 42.

${ }^{26}$ Ibid. 
with this issue is by regulating structure ${ }^{27}$. This is exactly the same approach being adopted in Article 27 of Competition Law.

In Grinnel case, the case suggests that in identifying monopoly power, one may examine its structural approach which is "ordinarily may be inferred from the predominant share of the market". ${ }^{28}$ In Alcoa case, the case provides three-tiered guidance on how to determine monopoly power: a firm with a $30 \%$ market share does not have monopoly power; a firm with a $60 \%$ share may have such power and a firm with a $90 \%$ share does have monopoly power ${ }^{29}$. In EU, especially in the early days of the EU merger control, the EU competition authority only interested to ban the merger which would only create or strengthen a dominance position ${ }^{30}$. It affirms the notion that only merger to dominance which would harm the market.

In contrary, the Chicago Schools refute those views ${ }^{31}$ as there are also positive effects that could be brought by big firms. These firms usually become dominant by its efficiency and rigorous innovation which is something that is not prohibited under the competition law ${ }^{32}$. Berkey Photo suggests that:

'It is the possibility of success in the market place, attributable to superior performance, that provides the incentives on which the proper functioning of our competitive economy rests. If a firm that has engaged in the risks and expenses of research and development were required in all circumstances to share with its rivals the benefits of those endeavors, this incentive would very likely be vitiated...because...a monopolist is permitted, and indeed encouraged, by Section 2 to compete aggressively on the merits, any success that it may achieve through "the process of invention and innovation" is clearly tolerated by the antitrust law.' ${ }^{33}$

Thus, there is nothing wrong by being big or dominant. United States $v$ United Shoe Machinery Corp adds that controlling a large market shares, if not monopolist, may only be subject to Section 2 of Sherman Act if it has power to exclude $^{34}$. It is further clarified in Verizon case whereby "the mere possession of monopoly power and the concomitant charging of monopoly price, is not only not unlawfull; it is an important element of the free market system"35. One may need to differentiate "the willful acquisiton or maintenance of that power as distinguished from growth or development as a consequence of a superior product, business acumen or historic accident"36. The same notion can also be

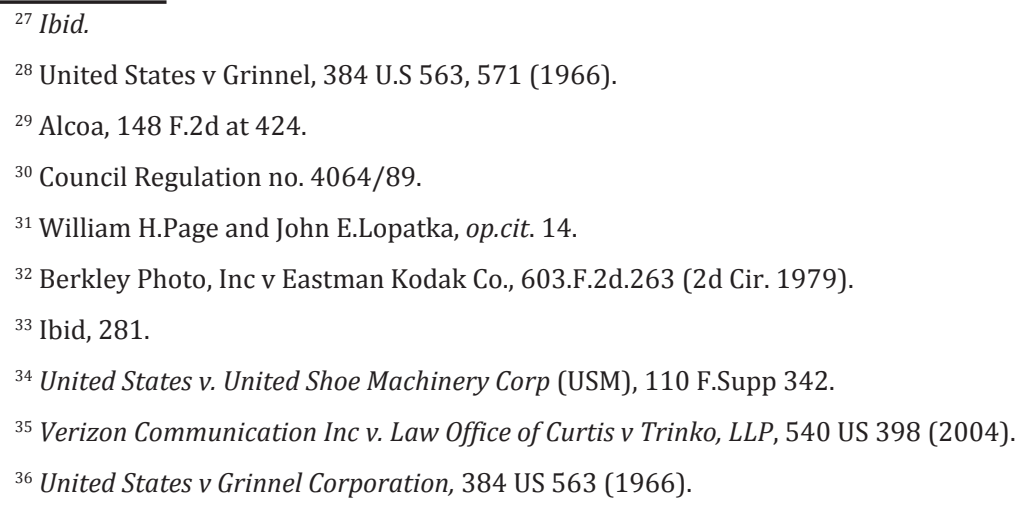


found in EU cases where a dominant company may only be subject to Article 102 TFEU if there is an abuse of its dominant position. In Akzo case, it alludes that "a dominant firm is entitled to compete on the merits" 37 since "dominant firms not only have the right but should be encouraged to compete on price... community competition law...should not offer less efficient undertakings a safe haven against vigorous competition even from dominant undertakings". ${ }^{38}$

Further, Hildebrand suggests that market power will accelerate innovation ${ }^{39}$. These dominant companies need to outperform their competitors with new and innovative products regardless the entry barriers are high or low. ${ }^{40}$ The innovation process and research and development are expensive and risky in which only a monopoly or a dominant company can afford research and development activities ${ }^{41}$. This condition would generally deter a competitive firm from involving in innovation process since it involves a lot of money and entails with uncertainty of the research outcomes ${ }^{42}$. Malecki believes that the innovation process arguably can only be done by large firms since they have sufficient resources to afford the research and able to take the risk associated with an innovation process ${ }^{43}$. From economics perspective, these firms can charge prices above marginal cost whose profit will be invested in research and development activities ${ }^{44}$. This is something that may be difficult for a firm operating in a competitive market since a 'price-taker' firm usually always equates its firm's marginal revenue equals with its marginal cost ${ }^{45}$. This actually is a normal profit. Thus, it leaves little room for these 'price-taker' firms to invest its profit in research and development activities since their profit arguably would only suffice to maintain its existence in the market ${ }^{46}$.

There are, however, certain critics that could be addressed to dominant companies. They tend to slow the innovation process as they lack of competitive pressures and tend to waste their resources ${ }^{47}$. On certain conditions, small firm

\footnotetext{
${ }^{37}$ ECS/AKZO, OJ 1985 L 374/1, para 81, upheld on appeal in Case C-62/86, AKZO Chemie BV v Commission [1991] ECR I-3359.

${ }^{38}$ Opinion of Advocate General Fennely in joined cases C-395/96 P and C-396/96P, Compagnie Maritime Belge Transports SA, Compagnie Maritime Belge SA and Dafra-Lines A/S v. Commission [2000] ECR $\mathrm{I}-1365$.
}

${ }^{39}$ D. Hildebrand, The European school, in EC Competition Law (2002) 25 World Competition 3-23, 8-9.

${ }^{40}$ Bhaskar Sastry, Market structure and incentives for innovation, 3 accessed via: http://www. intertic.org/Policy\%20Papers/Sastry.pdf. Please also see http://www.ftc.gov/opp/intellect/nelson.pdf

${ }^{41}$ United States v. American Can Co., 230 Fed. 859, 903 (D.Md.1916), appeal dismissed, 256 U.S 706, 41 S.Ct. 624 (1921).

${ }^{42}$ Bhaskar Sastry, op.cit, 2-3.

${ }^{43}$ Edward J Malecki, Technology and Economic Development $1^{\text {st }}$ ed (Longman Group UK Limited, 1991), 159

${ }^{44}$ Bhaskar Sastry, Market structure and incentives for innovation, June 2005, 2 (http://www. intertic.org/Policy\%20Papers/Sastry.pdf)

${ }^{45}$ Alison Jones \& Brenda Sufrin, EC Competition Law $3^{\text {rd }}$ ed (Oxford University Press, 2008), 7.

${ }^{46}$ Ibid.

${ }^{47}$ Alison Jones \& Brenda Sufrin, op.cit, 10. There are less pressure for the monopolist to invent and would tend to waste its resources. 
can become as vigorous as big company in the process of innovation ${ }^{48}$. One may conclude that the relationship between innovation and market structure is still unsettled as there are some evidences which suggest otherwise ${ }^{49}$. However, one cannot avoid the facts that most new innovations are coming from large companies, e.g. Microsoft, Apple, Google and Nokia. Specifically in the technology market, the competition takes place for the market and not within the market ${ }^{50}$. Thus, an innovation is a natural process in the technology market which one should not be worried of. Rajan, from a different angle, also emphasizes the need of concentration for the developing countries in getting better access to the market and source of finance. ${ }^{51} \mathrm{He}$ further suggests that a merger may often have a positive impact to the emerging countries. ${ }^{52}$

\section{A. Large market shares is not equal with market power}

Landes and Posner argued, however, that the inferences of power from market share alone can be misleading ${ }^{53}$. Further, the importance of market share to surrogate the market power has also been eroded ${ }^{54}$. In EU Horizontal Guidelines, it clearly considers market share only as one of elements, not the sole parameter, for preliminary merger assessment which is utilized as its initial screening test ${ }^{55}$.

It has been suggested that the inferences of power from market share alone can be misleading ${ }^{56}$ and the significant of market share has also been eroded in the context of merger analysis ${ }^{57}$. As mentioned earlier, the competition commission usually uses market share and concentration levels as their initial screening test ${ }^{58}$. The same approach is also taken in the US Horizontal Merger which relegates the roles of market shares as being only set as an initial screening test ${ }^{59}$. In Hoffman-La Roche case, the European Court of Justice also addressed the same notion which stated that the importance and relevance of market shares could be different from one market to another since the

\footnotetext{
${ }^{48}$ Ibid.

${ }^{49}$ Ibid.

${ }^{50}$ Giorgio Monti, Article 82 EC and the new economy markets in Cosmo Graham and Fiona Smith, Competition, Regulation and the New Economy (Oxford and Portland Oregon, 2004), 32.

${ }^{51}$ Rajan Dhanjee, Merger and developing countries trends, effects and policies 1993 (16(2)) 5, 8 $\& 11$.

${ }^{52}$ Ibid., 8

${ }^{53}$ William M. Landes and Richard A.Posner, Market power in antitrust case 94 Harv. L.Rev 937, 947.

54 The EU Horizontal Guidelines, paras 14 and 27.

${ }^{55}$ Ibid. George B. Shepherd, et.al, Sharper focus: market shares in the merger guidelines 45 Antitrust Bull 835, 874 .

${ }^{56}$ William M. Landes and Richard A.Posner, op.cit.

${ }^{57}$ Giorgio Monti, Article 82 EC and the new economy markets in Cosmo Graham and Fiona Smith, Competition, Regulation and the New Economy (Oxford and Portland Oregon, 2004), 32.

${ }^{58}$ George B. Shepherd, et.al, op.cit.

${ }^{59}$ Ibid. Please also see US 2010 Horizontal Merger Guidance at the FTC's website. (http://www.ftc. gov/os/2010/08/100819hmg.pdf)
} 
conditions of competition may differ ${ }^{60}$. Kroes also hesitated that high market shares alone could indicate market power without taking proper account of other competitive factors:

This means that I consider that high market shares are not - on their own - sufficient to conclude that a dominant position exists. Market share presumptions can result in an excessive focus on establishing the exact market shares of the various market participants. A pure market share focus risks failing to take proper account of the degree to which competitors can constrain the behaviour of the allegedly dominant company. That is not to say that market shares have no significance. They may provide an indication of dominance - and sometimes a very strong indication - but in the end a full economic analysis of the overall situation is necessary ${ }^{61}$.

Landes and Posner clearly expressed that large market share alone is not equal with market power ${ }^{62}$. In determining the market power, it needs two other parameters namely, demand-side substitution and supply-side substitution ${ }^{63}$.

Furthermore, there are certain conditions in which the monopolist could not unilaterally increase its price because the monopolist has already priced its products at the supra-competitive price ${ }^{64}$. Once the monopolist tries to increase the price, the customer will switch swiftly to the next available supplier ${ }^{65}$. The same condition would also occur where entry is relatively easy in which the new entrant may very well replace the incumbent in no time at all (especially in the new technology market) ${ }^{66}$. It would inevitably induce new comers to enter the relevant market since it promises a high return of investment.

The rapid development in the new technology market could erode the significance of market share ${ }^{67}$ The special characteristic of the new technology market is that the competition is "for the market"68. It is an exercise on continuous innovation and creation of new products in order to survive ${ }^{69}$. The repositioning by the non-merging firms is always there and be ready to take the market once they have the opportunity ${ }^{70}$. It confirms the notion that market power is equal with large market share is misleading ${ }^{71}$. In light of this,

${ }^{60}$ Case 85/76 Hoffman-La Roche \& Co AG v. Commission [1979] ECR 46, para 41.

${ }^{61}$ Neelie Kroes, Preliminary thoughts on policy review of article 8229 Fordham Int'l L.J. 593, 594-5.

${ }^{62}$ William M. Landes and Richard. A. Posner, op.cit, 945-947.

${ }^{63}$ Ibid. Keith N. Hylton, Antitrust Law Economic Theory \& Common Law Evolution $1^{\text {st }}$ edn (Cambrige University Press 2003), 236.

${ }^{64}$ Alison Jones and Brenda Sufrin, ,70-71.

${ }^{65}$ Ibid.

${ }^{66}$ William M. Landes and Richard A. Posner, op.cit, 947-950.

${ }^{67}$ Giorgio Monti, op.cit.

${ }^{68}$ Christian Ahlborn, et.al, Competition policy in the new market: is European competition law up to the challenge (2001) ECLR 156, 160.

${ }^{69}$ Ibid., 159.

70 Ibid.

${ }^{71}$ Case 85/76 Hoffman-La Roche \& Co AG v. Commission [1979] ECR 46, paras 38-39. 
there is more than just the concentration issue, the pertinent conditions and characteristics surrounding the relevant market should also need to be taken into account in order to describe the valid market power of such undertakings. ${ }^{72}$

The above explanation may very well dispute the inference of market power that could only come from a post-merger monopoly or party having a large market share which emerged in Oracle/PeopleSoft case ${ }^{73}$. In Oracle/ PeopleSoft case, the court was convinced that the only way the merging firm could unilaterally increase its prices profitably is by having a post-merger monopoly or dominant position ${ }^{74}$. The court required a significant share of sales in the market that could make a small but significant non-transitory increase in price (SSNIP) profitable ${ }^{75}$. This may lead to a suspicion that this merger may lead to the increase of price. There are cases where the inference of market power is linked to the market share of the respective undertaking ${ }^{76}$. At a glance, it appears to be a convincing argument but it is not entirely true, primarily from the economic perspective. The court seemed to reject this notion since the plaintiff fails to establish a proper market definition by excluding certain parties, e.g Microsoft and other sourcing companies. The court views that "Microsoft will be a viable substitute for a significant number of consumers should a post-merger Oracle imposes a SSNIP in its pricing of ERP software"77. It shows that a low entry barrier could constrain the ability of the "dominant company" to raise its price in such market.

Furthermore, in Oracle/Sun Microsoft case, the merger between Oracle and Sun Microsystem was suspected by the EU Commission to have anticompetitive effects considering the fact that the database market was already highly concentrated ${ }^{78}$. This particular market has been controlled by Oracle, IBM and Microsoft which represented more than 80 percent $^{79}$. However, after taking an in-depth investigation, the EU Commission held that the proposed merger had no significant structural effect on EU market and cleared the merger ${ }^{80}$ since another competitor, PostgreSQL ${ }^{81}$, could become a credible competitor to constrain Oracle in a timely and sufficient manner ${ }^{82}$.

\footnotetext{
${ }^{72}$ William M. Landes and Richard A. Posner, op.cit, 947-950.

${ }^{73}$ United States v. Oracle Corp, No. C 04-0807 (finding of fact, conclusion of law and order) (2004), $124-130$

${ }^{74}$ Ibid.

${ }^{75}$ Jonathan B. Baker et.al, Roundtable discussion on unilateral effects analysis after Oracle (20042005) 19 Antitrust 8, 15.

${ }^{76}$ United States v. Alumunium Co of America (Alcoa), 148 F.2d 416, 424 (1995); United States v United Shoe Machinery Corp 110 F.Supp.295 (D.Mass.1953).

77 Ibid.

${ }^{78}$ Case No. COMP/M.5529 Oracle/Sun Microsystems (2010) OJ C 91/7, para 19.

${ }^{79}$ Ibid.

${ }^{80}$ Ibid., paras 72-73.

${ }^{81}$ PostgreSQL is an open source relational database management system derived from the Ingress project at the University of California, Berkeley (Ibid, para 13).

82 Ibid, para 41.
} 


\section{Concentrations and Developing Countries}

It has been held that the relationship between merger control regime and developing countries are dilemmatic ${ }^{83}$. The debate focuses on two extreme polars whether the merger control is ever needed in the emerging countries or should a merger control be abandoned entirely ${ }^{84}$. One has argued that a merger control is required for developing countries to prevent market distortions caused by dominant undertakings ${ }^{85}$. These undertakings generally have relationship with certain number of political power-connected families' circles and have the tendency to be abusive ${ }^{86}$. For this reason, the intervention of merger control is needed to protect or prevent the market from such distortion ${ }^{87}$. Furthermore, a weak protection to consumers which is mostly found in developing countries adds more raison d'être to have a specific legal instrument (i.e. merger control) which could be enforced against the abusive undertakings. ${ }^{88}$ Clearly, these conditions have analogous with the past conditions in Indonesia which create an impetus to adopt the Competition Law in Indonesia.

In contrast, there are also fervent views which suggest that a merger control should be abandoned by developing countries ${ }^{89}$. It is partly because the economic characteristic of those developing countries have not yet reach their economies of scale, scarcity of resources and lack of financial resources aspects. ${ }^{90}$ Stewart persuasively alludes that "many developing countries assert that merger control regime is not appropriate for their economies. It is argued that firms cannot achieve international competitiveness without economies of scale and that in small economies this could require the creation of monopolies or substantial market power in the domestic market ${ }^{91 "}$.

In South Korea, its competition authority encouraged the creation of concentration in the preliminary stages of its industry development so that they could compete vigorously in a world market competition ${ }^{92}$. Hoekman clarifies

${ }^{83}$ Taimoon Stewart, et.al, Competition law in action experiences from developing countries (Canada's International Development Research Centre, 2007), 7 \& 24.

${ }^{84}$ Ibid.

${ }^{85}$ Pande Radja Silalahi, op.cit. 10.

${ }^{86}$ Prior to the enactment of Competition Law, the policy makers and the stakeholders had concluded that these kinds of relationships (relationship between business persons and political elite) had caused severe market distortions in Indonesia. Please see United Nations Committee on Trade and Development (UNCTAD), Voluntary peer review on competition law: Indonesia (UNCTAD, 2009), 22, accessed via http:// www.unctad.org/en/docs/ditcclp20091en_.pdf (03 June 2010).

${ }^{87}$ Ibid. 23.

${ }^{88}$ Michal Gal, The ecology of antitrust: preconditions for competition law enforcement in developing countries in Competition, Competitiveness and Development: Lessons from Developing Countries compiled and edited by UNCTAD (2004), 12. Please see http://www.unctad.org/en/docs//ditcclp20041ch1_en.pdf. Please also see Thomas B Leary, Competition law and consumer protection law: two wings of the same houses. This article can be accessed via: http://www.ftc.gov/speeches/leary/041022learyarticle.pdf

\footnotetext{
${ }^{89}$ Taimoon Stewart, et.al, op.cit.

${ }^{90}$ Rajan Dhanjee, op.cit, 11.

${ }^{91}$ Taimoon Stewart, et.al, op.cit,24.

${ }^{92}$ Rajan Dhanjee, op.cit, 18.
} 
that high concentration ratios do not necessarily relfect a lack of competition ${ }^{93}$. Posner also disputed the populist notion that competition policy should restrict large business firms' activities for the protection of small business ${ }^{94}$. He further added that small business to a certain extent tend to raise price above the competition level..$^{95}$

Learning from Indonesia's experience, a merger control is indeed required for emerging countries. However, every country has the right to implement its merger control in accordance with its own economic characteristics and conditions $\mathrm{s}^{96}$. It is implied that developing countries can apply a merger control regime in their countries only if they take into account the following aspects, among others: (i) their economics characteristic, (ii) relatively concentrated nature of most product markets, (iii) concentration of ownership, (iv) shortage of finance, and ( $v$ ) the importance of economies of scale and economices of scope $^{97}$. Inevitably, the above conditions should be included to our attention. Further, a report gives an insight that the access for obtaining a financing via global capital markets in Indonesia is still low (4.12\% from the total GDP of Indonesia) ${ }^{98}$ and only 420 companies in Indonesia which have been listed in the Indonesian Stock Exchange. ${ }^{99}$ It suggests that the creation of concentration in emerging countries including Indonesia is still essential to reach our economies of scale and competitiveness ${ }^{100}$.

Likewise, the Indonesian merger control must also harmonize its industrial strategy and competition policy so that it can achieve consumer welfare effectively. In Indomaret case, KPPU has taken a view that the competition process should be protected by preserving an equal business opportunities for large, medium, and small-scale business business actors ${ }^{101}$. Although this case was not a merger case, however, one should appreciate that KPPU has initiatively taken a step forward to protect the competition process in Indonesia. This is something that can be applied in the merger context.

Our strategic policy actually has been asserted in Articles 2 and 3 of the Competition Law.

\footnotetext{
${ }^{93}$ Bernard Hoekman, Economic development, competition policy and the WTO, 8 April 2003, 6. This can be accessed via: http://papers.ssrn.com/sol3/papers.cfm?abstract_id=636279.

${ }^{94}$ Richard Posner, op.cit, 24-25,

95 Ibid.

${ }^{96}$ Pradeep S. Mehta, Competition Policy in developing countries: an asia pacific perspective (Bulletin on Asia-Pasific Perspective 2002/03), 81. This can be accessed via http://www.unescap.org/drpad/ publication/bulletin\%202002/ch7.pdf.

${ }^{97}$ Rajan Dhanjee, op.cit, 6.

${ }^{98} \mathrm{http}: / /$ www.tradingeconomics.com/indonesia/financing-via-international-capital-marketsgross-inflows-percent-of-gdp-wb-data.html
}

99 http://www.tradingeconomics.com/indonesia/listed-domestic-companies-total-wb-data. html. In Australia, it has more than 2,000 companies listed in the Australia Securities Exchange (please see http://www.asx.com.au/asx/research/listedCompanies.do ). Similarly in US Nasdaq, it has also more than 2,500 companies listed in Nasdaq (please see http://www.nasdaq.com/screening/companies-byindustry.aspx? exchange=NASDAQ ).

100 Taimoon Stewart, et.al, op.cit. 7 \& 24.

${ }^{101}$ Case No. 03/KPPU-L-I/2000 on PT Indomarco Prismatama's retail business, para 32 letter (d). 


\section{Article 2}

Business actors in Indonesia in doing their business, shall be based on economic democracy, with due attention to the equilibrium between the business actors' interest and the public interest.

\section{Article 3}

The purpose of enacting this act shall be to:

a. safeguard the public interests and to increase the national economic efficiency as one of the efforts to increase the people's welfare;

b. establish a conducive business climate through the arrangement of fair business competition thus guaranteeing the certainty of equal business opportunities for large, middle and small-scale business actors in Indonesia;

c. prevent monopolistic practices and/or unfair business competition caused by business actors; and

d. the creation of effectiveness and efficiency in business activities.

For this reason, the implementation of Article 27 demands a new approach which could protect the Indonesian market and enhance its competitiveness. This new approach can be done either by amending the Article 27 or by revising the KPPU Guidance Article. 27. It is perhaps preferred to take the latter route since such process is generally within the sole control of the KPPU which is less costly and time consuming than amending the Competition Law. ${ }^{102}$ In a way, KPPU could also be flexible to apply Article 27 if such provision may no longer suitable with market conditions at a certain time. One may note this on Temasek case in which KPPU effectively has applied a'rule of reason' approach in a 'per $s e^{\prime}$ provision - a case which can be set as a standard for the future development of Article 27.

Then again, one would anticipate that the above would be heavily criticized by the Chicago Schools which hold the view that competition law should not pursue objectives other than economic efficiency ${ }^{103}$. It must pursue the maximization of consumer welfare or economic efficiency as it would create prosperity for the society ${ }^{104}$. On this, one may respond that by promoting a national economy, it could be considered as pursuing economic efficiency since at the end of the day this process would enhance the consumer welfare of Indonesia - an objective which must be pursued by the Competition Law. ${ }^{105}$

\footnotetext{
${ }^{102}$ Competition Law, Art. 35 letter (f).

${ }^{103}$ Herbert Hovenkamp, Antitrust policy after Chicago (1985-1986) 84 Mich.L.Rev. 213, 226-229.

${ }^{104}$ Robert H. Bork, op.cit. 426-429.

${ }^{105}$ Article 2 of Competition Law states that "business actors in Indonesia in doing their business, shall be based on economy democracy, with due attention to the equilibrium between the business actors'
} interest and the public interest". 


\section{Article 27 going forward}

Article 27 reveals many drawbacks as it stands on inaccurate assumptions. Being big is not necessarily bad, and controlling a large market share does not equal to possessing a market power. The current structure of Article 27 could arguably restrict any mergers which meets its test without assessing their effects to the market (including those mergers which has valid business justifications and offer efficiency). Clearly, this is a situation that needs to be avoided by the KPPU since it could potentially bring significant losses to the Indonesian economics in a wider spectrum. One may need to appreciate the positive effects that may be created from a merger, even if it does create a dominant company. In light of this, an extensive merger review is required by KPPU in applying Article 27.

This, however, does not mean that KPPU may need to loosen its supervision on its merger control, especially for those mergers which would create a dominant company. However, if one only solely focuses on a market concentration to block the merger, it may give the wrong signal to the market and its mistakes are likely to be costly. It would be wise, however, if KPPU, in applying Article 27, would balance the economics factors and Indonesian's strategic industry policy in managing the future development of merger control in Indonesia.

\section{Conclusion}

Article 27 of Law No. 5 Year 1999 on the Restriction of Monopoly Practices and Unfair Business Practices ("Competition Law") restricts any merger which basically controls (i) more than 50\% for one undertaking or (ii) more than $75 \%$ along with two or three undertakings. Article 27 rests under two main assumptions which are (a) acquiring a large market shares or creating an oligopolistic market would bring no benefit to the market or society. In a simple word, being big is bad and (b) controlling a large market share equals to possessing a market power. These notions were supported with two cases which involved Article 27 as its main contention i.e. Cineplex 21 case $^{106}$ and Temasek case ${ }^{107}$. Interestingly, KPPU has taken different approaches to these cases. However, if one only solely focuses on a market concentration to block the merger, it may give the wrong signal to the market and its mistakes are likely to be costly. It would be wise, however, if KPPU, in applying Article 27, would balance the economics factors and Indonesian's strategic industry policy in managing the future development of merger control in Indonesia.

\section{Bibliography}

\section{Book}

Bork, Robert (1978). The Antitrust Paradox.

Cooter, Robert, and Thomas Ulen (2004). Law \& Economics 4th ed., (Pearson Addison Wesley).

${ }^{106}$ KPPU Case No. 05/KPPU-L/2002 on Cineplex 21.

${ }^{107}$ KPPU Case No.07/KPPU-L/2007 on Temasek (divestment of Indosat). 
Graham, Cosmo and Fiona Smith (2004). Competition, Regulation and the New Economy (Oxford and Portland Oregon).

Hovenkamp, Herbert (2005). Federal Antitrust Policy The Law of Competition and its Practices 3rd ed. (Thomson West).

Hylton, Keith N (2003). Antitrust Law Economic Theory \& Common Law Evolution 1st (Cambrige University Press).

Jones, Alison and Brenda Sufrin (2008) EC Competition Law 3rd ed. (Oxford University Press)

Malecki, Edward J. (1991). Technology and Economic Development 1st ed. (Longman Group UK Limited).

Page, William H. Page and John E.Lopatka (2007). The Microsoft Case, Antitrust, High Technology and Consumer Welfare 1st ed., (University Chicago Press).

Posner, Richard (2001). Antitrust Law 2nd ed., (Chicago Press).

\section{Article}

Ahlborn, Christian, et.al, (2001). Competition policy in the new market: is European competition law up to the challenge ECLR 156 - 167.

Baker, Jonathan B, et.al, (2004-2005). Rountable discussion on unilateral effects analysis after Oracle 19 Antitrust 8-19.

Dhanjee, Rajan, (1993). Mergers and developing countries - trends, effects and policies World Competition 5.

Hoekman, Bernard (2003). Economic development, competition policy and the WTO, 8 April 2003.

Kroes, Neelie (2005). Preliminary thoughts on policy review of article 8229 Fordham Int'l L.J., 593 - 600.

Landes, William M and Richard A. Posner, (1981). Market power in antitrust case 94 Harv. L.Rev 937 - 996.

Mehta, Pradeep, (2002/03). Competition policy in developing countries: an asia pasific perspective (bulletin on Asia-Pacific Perspective 2002/03).

Mueller, DC, (1982). A theory of conglomerate merger Quarterly Journal of Economics 643 - 659.

Sastry, Bhaskar, (2005). Market structure and incentives for innovation (June 2005).

Shepherd, George B, et.al, (2000). Sharper focus: market shares in the merger guidelines 45 Antitrust Bull 835 - 886.

Silalahi, Pande Radja, Urgency of competition law.

Stewart, Taimoon, et.al, (2007). Competition law in action experiences from developing countries (Canada's International Development Research Centre, 2007).

Turner, Donald F., (1965). Conglomerate merger and section 7 of the Clayton Act 78 Harv.L.R. 1313 - 1395.

UNCTAD, (2004). Competition, competitiveness and development: lessons from developing countries (UNCTAD,). 
UNCTAD, (2009) Voluntary peer review on competition law, Indonesia (UNCTAD).

\section{Indonesian Cases}

KPPU Case No. 03/KPPU-L-I/2000 on PT Indomarco Prismatama. KPPU Case No. 05/KPPU-L/2002 on Cineplex 21.

KPPU Case No. 07/KPPU-L/2007 on Temasek (divesment in Indosat).

\section{EU Cases}

Case C-62/86, AKZO Chemie BV v Commission [1991] ECR I-3359.

Cases C-395/96 P and C-396/96P, Compagnie Maritime Belge Transports SA, Compagnie Maritime Belge SA and Dafra-Lines A/S v. Commission [2000] ECR I-1365.

Case 85/76 Hoffman-La Roche \& Co AG v. Commission [1979] ECR 46.

Case No Comp/M.5529 Oracle/Sun Microsystems [2010] OJ C 91/7.

\section{US Cases}

Berkley Photo, Inc v Eastman Kodak Co. 603.F.2d.263 (2d Cir.1979).

United States v Almunium Co of America (Alcoa) 148 F.2d.416, 424 (1995).

United States v. American Can Co., 230 Fed.859, 903 (D.Md.1916), appeal, dismissed, 256 U.S 706, 41 S.Ct. 624 (1921).

US v. Grinnel 384 U.S 563, 571 (1966).

United States v. Oracle Corp, No. C 04-0807 (finding of fact, conclusion of law and order) (2004).

United States v United Shoe Machinery Corp 110 F.Supp.295 (D.Mass.1953).

Verizon Communication Inc v. Law Office of Curtis v Trinko, LLP, 540 US 398 (2004)

\section{Websites}

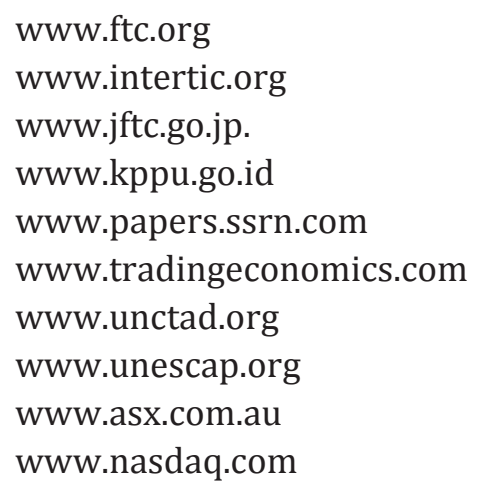

